\title{
Effect of Drip Fertigation on Productivity and Economics of Maize (Zea mays L.) in Eastern Dry Zone of Karnataka, India
}

\author{
Richa Khanna $^{1^{*}}$, T. Sheshadri ${ }^{1}$ and Subhash Chandra ${ }^{2}$ \\ ${ }^{I}$ Department of Agronomy, College of Agriculture, University of Agricultural Sciences, \\ GKVK, Bangalore, Karnataka, India \\ ${ }^{2}$ Department of Agronomy, College of Agriculture, GBPUA\&T, Pantnagar, India \\ *Corresponding author
}

Keywords

Maize, Drip fertigation, Water soluble fertilizers, Cob yield, Net returns, B: $\mathrm{C}$ ratio

Article Info

Accepted:

07 April 2018

Available Online:

10 May 2018

\section{A B S T R A C T}

Drip fertigation is known to enhance the growth and productivity of various crops. Since maize is a heavy feeder of nutrients and water, thus, proper management of these resources is the key to successful growth of maize. Keeping this in view, a field experiment was conducted at Zonal Agricultural Research Station, UAS, GKVK, Bangalore, during kharif season of 2012, to study the effect of drip irrigation and fertigation with different levels and sources of fertilizers on productivity and economics of maize. The experiment consisted of ten treatments laid out in Randomized Complete Block Design with three replications. The experimental results indicated that drip fertigation with $125 \%$ RDF through water soluble fertilizers produced the maximum grain yield $\left(11.9 \mathrm{t} \mathrm{ha}^{-1}\right)$, which was on par with drip fertigation with $100 \%$ RDF through water soluble fertilizers $(11.3 \mathrm{t}$ $\mathrm{ha}^{-1}$ ). The lowest grain yield was recorded with surface irrigation with $100 \% \mathrm{RDF}$ through normal fertilizers $\left(7.9 \mathrm{t} \mathrm{ha}^{-1}\right)$. Decrease in RDF to $50 \%$ in drip fertigation system has resulted in lower grain yields with both water soluble and normal fertilizers. However, highest net returns and $\mathrm{B}$ : C ratio was obtained with drip fertigation with $125 \% \mathrm{RDF}$ through NF (Rs $92734 \mathrm{ha}^{-1}$ and 3.46, respectively) which was on par with $100 \%$ RDF through NF (Rs 90614 ha $^{-1}$ and 3.46, respectively).

\section{Introduction}

Maize (Zea mays L.) is an important cereal crop after wheat and rice and being the queen of cereal crops it is known for its higher productivity. In India maize is grown on an area of 8.7 million ha with a production of 21.8 million tonnes and Karnataka is one of the major maize producing states of India where maize is grown on an area of 1.2 million ha with a production of 3.3 million tonnes (Mahajan, 2017). In Karnataka maize has recorded a productivity of $2773 \mathrm{~kg} / \mathrm{ha}$ which is even higher than the national average of $2509 \mathrm{~kg} / \mathrm{ha}$ (Mahajan, 2017). The production potential of hybrid maize is not fully harnessed even under irrigated conditions. This might be due to improper management of resources like nutrients and water. In intensive agriculture, the key contributing factors are nutrient and water but, the optimum and précised use of these inputs are of utmost importance because they are scarce as well as costly. Therefore, it is 
becoming essential to use agro techniques which can save these precious inputs. The introduction of simultaneous micro irrigation and fertilizer application opens new possibilities for controlling the water and nutrient supplies to crops. It is based on the principle of précised application of water and nutrients to plants in the root zone through drip irrigation system. Drip fertigation offers several advantages like higher yield and productivity (Fanish et al., 2011), enhanced nutrient and water saving, uniform availability of water and nutrients by maintaining their desired concentration in the soil (Douh and Boujelben, 2011 and Hassanli et al., 2009). From environmental point of view drip fertigation offers an advantage of reduced nitrate leaching and thereby reducing the ground water pollution. Asadi et al., (2002) also reported that maize crop produced same yield with application of 150 and $200 \mathrm{~kg} \mathrm{~N} / \mathrm{ha}$. They also observed higher amount of nitrate leaching with application of $200 \mathrm{~kg} \mathrm{~N} / \mathrm{ha}$ as compared to $150 \mathrm{~kg} \mathrm{~N} / \mathrm{ha}$. Drip fertigation enables us to get higher yield with low doses of nutrients applied. So, they not only results in nutrient savings but also minimize environmental hazards.

\section{Materials and Methods}

The field experiment was done at Zonal Agricultural Research Station, UAS, GKVK, Bangalore, India, which is situated in the Eastern Dry Zone (Zone - 5) of Karnataka between $12^{\circ} 51^{\prime} \mathrm{N}$ Latitude and $77^{\circ} 35^{\prime} \mathrm{E}$ Longitude at an altitude of $930 \mathrm{~m}$ above MSL, during kharif 2012.

The objective was to find out the best water and nutrient management practices that enhances the productivity of maize crop and provides maximum returns. The experimental site had a sandy clay loam soil, which had $0.56 \%$ available organic carbon (Walkley and Black, 1934), $362.49 \mathrm{~kg} / \mathrm{ha}$ available $\mathrm{N}$
(Subbiah and Asija, 1956), $62.33 \mathrm{~kg} / \mathrm{ha}$ available P (Oleson et al., 1954) and 273.20 $\mathrm{kg} / \mathrm{ha}$ available K (Black, 1971). The soil reaction was acidic with a $\mathrm{pH}$ of 5.56 (Jackson, 1973). The total rainfall received during the period of experiment (August to December) was $354.70 \mathrm{~mm}$ which was $39.1 \%$ less as compared to normal average rainfall of that season $(582.30 \mathrm{~mm})$. The mean maximum and minimum temperature ranged from 27.2 to $28.3{ }^{\circ} \mathrm{C}$ and 15.7 to $19.4{ }^{\circ} \mathrm{C}$, respectively.

The experiment was laid out in Randomized Complete Block Design with ten treatments and three replications. The treatments were: $\mathrm{T}_{1}$ - surface irrigation with soil application of $100 \%$ RDF (Normal Fertilizers: NF), $\mathrm{T}_{2}$ - Drip irrigation with soil application of $100 \%$ RDF (NF), $\mathrm{T}_{3}$-Drip fertigation with $50 \% \mathrm{RDF}$ (NF), $\mathrm{T}_{4}$-Drip fertigation with $75 \% \mathrm{RDF}$ (NF), $\mathrm{T}_{5}$-Drip fertigation with $100 \% \mathrm{RDF}$ (NF), $\mathrm{T}_{6}$-Drip fertigation with $125 \% \mathrm{RDF}$ (NF), $\mathrm{T}_{7}$-drip fertigation with $50 \%$ RDF (Water Soluble Fertilizers: WSF), $\mathrm{T}_{8}$-Drip fertigation with $75 \%$ RDF (WSF), $\mathrm{T}_{9}$ - Drip fertigation with $100 \%$ RDF (WSF), $\mathrm{T}_{10}$-Drip fertigation with $125 \%$ RDF (WSF).

Seeds of hybrid maize 'Hema' ('NAH 1137') were sown on $17^{\text {th }}$ August 2012, at a spacing of $60 \times 20 \mathrm{~cm}$. In treatments $\mathrm{T}_{1}$ and $\mathrm{T}_{2}$ fertilizers were applied as per package of practices i.e. $50 \%$ of nitrogen along with entire dose of phosphorus and potassium as basal dose and remaining $50 \%$ was applied in two equal splits at 25 and 45 DAS. In rest of the treatments whole amount of fertilizer was applied through drip fertigation. Recommended dose of fertilizer was 150:75:40 kg N, $\mathrm{P}_{2} \mathrm{O}_{5}$ and $\mathrm{K}_{2} \mathrm{O}$, ha ${ }^{-1}$. Zinc Sulfate @10 kg ha ${ }^{-1}$ was applied uniformly to all the treatments through surface application. Normal fertilizers used were: Urea, Diammonium Phosphate, Single Super Phosphate and water soluble fertilizers used were: Calcium Nitrate, 19:19:19 and 12:61:0. 
Two irrigations of $3 \mathrm{~cm}$ each were given in general to all the plots after sowing. Drip irrigation was started on $16^{\text {th }}$ DAS i.e. on $2^{\text {nd }}$ September 2012. Water through drip system was provided on the basis of CPE values at an interval of 2-3 days. The drip discharge was 2 lph and emitter spacing was $30 \mathrm{~cm}$. Fertigation treatments were also imposed on same day and whole amount of fertilizer was divided into 8 equal splits and they were given to crop at an interval of every 8 days through drip. The irrigation to $T_{1}$ was provided on the basis of visual observations and critical stage approach.

To ensure proper weed management, pre emergence application of atrazine was done @ $1 \mathrm{~kg}$ a.i./ha by mixing it with sand and spreading it uniformly over the cropped area which was followed by one hand weeding at 25 DAS. To control the incidence of downy mildew disease, two sprays of Ridomil MZ @ $3 \mathrm{~g} / \mathrm{l}$ were done. Earthing up was done at 45 DAS to ensure protection against lodging. Harvesting was done on $16^{\text {th }}$ December 2012. For data collection five tagged plants were selected from every plot and all the observations were recorded using the same plants. The data were analyzed using analysis of variance (ANOVA) technique as applicable for Randomized Complete Block Design (Rangaswamy, 2006). The results were interpreted on the basis of F- test and critical difference at $5 \%$ was used for calculating the significant difference between the means of two treatments (Gomez and Gomez, 1984).

\section{Results and Discussion}

\section{Yield contributing characters and yield}

Crop productivity is affected by both internal and external factors; nutrient and water availability are the most dominant external factors among them. The crop received 39.1 per cent less rain fall as compared to normal rainfall of that season, still the crop responded very well to drip fertigation. Data collected on yield attributes (Table 1) revealed that significantly highest cob length was obtained with drip fertigation with $125 \%$ RDF through WSF which was at par with drip fertigation with $100 \%$ RDF through WSF. Similar trend was recorded by cob weight per plant. The significantly higher number of rows per cob was observed with drip fertigation with $125 \%$ RDF through WSF followed by drip fertigation with $100 \%$ RDF through NF. This may be due to increased availability of water and nutrients in the soil and their uptake by crop, thus resulted in better yield attributes. Similar results were recorded by Patil et al., (2011) in maize.

An increase in the maize yield was observed due to increased doses of fertilizers (Table 2). Drip fertigation with $125 \%$ RDF through WSF has recorded $49.4 \%$ higher yield as compared to surface irrigation and $29.47 \%$ higher as compared to drip irrigation (in both treatments soil application of $100 \%$ RDF through NF was done). However, yield obtained in drip fertigation with $125 \%$ RDF through WSF was statistically at par with drip fertigation with $100 \%$ RDF through WSF and drip fertigation with 125 per cent RDF through NF.

This may be attributed to the reason that plants have efficiently utilized the higher concentration of nutrients present in the root zone. Higher nutrient uptake has resulted in more biomass accumulation and more translocation of photosynthates towards the sink i.e. grains. Hassanli et al., 2009 also reported that maize crop irrigated with sub surface drip and surface drip methods have shown statistically similar yield but it was significantly higher as compared to surface furrow irrigation method; which was attributed to uniform distribution of irrigation water and lesser evapotranspiration. 
Table.1 Effect of water and nutrient management practices on yield attributes of maize crop

\begin{tabular}{|c|c|c|c|c|c|}
\hline Treatments & $\begin{array}{l}\text { Cob length } \\
(\mathrm{cm})\end{array}$ & $\begin{array}{c}\text { Number of } \\
\text { rows }\end{array}$ & $\begin{array}{c}\text { Number of } \\
\text { Grains per row }\end{array}$ & $\begin{array}{l}\text { Cob weight/ } \\
\text { plant (g) }\end{array}$ & $\begin{array}{c}\text { Grain weight/ } \\
\text { plant }(\mathrm{g})\end{array}$ \\
\hline $\mathrm{T}_{1}$ : Surface irrigation with soil application -100 \% RDF (NF) & 12.3 & 15.3 & 30.7 & 159.9 & 108.3 \\
\hline $\mathrm{T}_{2}$ : Drip irrigation with soil application- $100 \%$ RDF (NF) & 12.9 & 15.6 & 35.2 & 172.2 & 110.5 \\
\hline $\mathrm{T}_{3}:$ Drip fertigation - $50 \%$ RDF (NF) & 11.6 & 13.8 & 26.0 & 155.9 & 101.8 \\
\hline $\mathrm{T}_{4}$ : Drip fertigation- $75 \%$ RDF (NF) & 12.0 & 15.1 & 31.6 & 168.8 & 113.1 \\
\hline $\mathrm{T}_{5}:$ Drip fertigation $-100 \%$ RDF (NF) & 13.9 & 17.9 & 36.8 & 180.7 & 128.6 \\
\hline $\mathrm{T}_{6}:$ Drip fertigation -125 \% RDF (NF) & 14.1 & 18.6 & 39.1 & 184.4 & 134.4 \\
\hline $\mathrm{T}_{7}:$ Drip fertigation - 50 \% RDF (WSF) & 11.8 & 14.9 & 28.8 & 149.2 & 106.8 \\
\hline$T_{8}:$ Drip fertigation - $75 \%$ RDF (WSF) & 14.3 & 17.8 & 38.7 & 182.1 & 135.1 \\
\hline $\mathrm{T}_{9}$ : Drip fertigation - $100 \%$ RDF (WSF) & 14.9 & 18.3 & 39.8 & 186.3 & 137.1 \\
\hline $\mathrm{T}_{10}$ : Drip fertigation - $125 \%$ RDF (WSF) & 15.6 & 19.3 & 41.8 & 196.5 & 147.8 \\
\hline S.Em \pm & 0.3 & 0.3 & 1.5 & 4.4 & 4.4 \\
\hline C.D. at $5 \%$ & 0.9 & 0.9 & 4.5 & 13.2 & 13.6 \\
\hline
\end{tabular}

Table.2 Effect of water and nutrient management practices on yield and economics of maize crop

\begin{tabular}{|c|c|c|c|c|c|}
\hline Treatments & $\begin{array}{c}\text { Grain yield } \\
\left(\mathbf{t} \mathbf{h a}^{-1}\right)\end{array}$ & $\begin{array}{l}\text { Cost of cultivation } \\
\text { (Rs./ha) }\end{array}$ & $\begin{array}{l}\text { Gross returns } \\
\text { (Rs./ha) }\end{array}$ & $\begin{array}{l}\text { Net returns } \\
\text { (Rs./ha) }\end{array}$ & B:C Ratio \\
\hline $\mathrm{T}_{1}$ : Surface irrigation with soil application -100 \% RDF (NF) & 7.9 & 32643 & 95280 & 62637 & 2.9 \\
\hline $\mathrm{T}_{2}$ : Drip irrigation with soil application- $100 \%$ RDF (NF) & 9.2 & 37726 & 109920 & 72194 & 2.9 \\
\hline $\mathrm{T}_{3}$ : Drip fertigation - $50 \%$ RDF (NF) & 7.1 & 35060 & 84840 & 49780 & 2.4 \\
\hline $\mathrm{T}_{4}:$ Drip fertigation- $75 \%$ RDF (NF) & 9.0 & 35942 & 108000 & 72058 & 3.0 \\
\hline$T_{5}:$ Drip fertigation -100 \% RDF (NF) & 10.6 & 36826 & 127440 & 90614 & 3.5 \\
\hline$T_{6}:$ Drip fertigation -125 \% RDF (NF) & 10.9 & 37706 & 130440 & 92734 & 3.5 \\
\hline $\mathrm{T}_{7}$ : Drip fertigation - $50 \%$ RDF (WSF) & 8.6 & 58825 & 103560 & 44735 & 1.8 \\
\hline$T_{8}$ : Drip fertigation - $75 \%$ RDF (WSF) & 10.3 & 71534 & 123960 & 52426 & 1.7 \\
\hline $\mathrm{T}_{9}$ : Drip fertigation - $100 \%$ RDF (WSF) & 11.3 & 84355 & 135480 & 51125 & 1.6 \\
\hline$T_{10}:$ Drip fertigation - $125 \%$ RDF (WSF) & 11.9 & 96919 & 142320 & 45401 & 1.5 \\
\hline S.Em \pm & 0.4 & NA & 4524.6 & 4524.6 & 0.1 \\
\hline C.D. at $5 \%$ & 1.1 & NA & 13443 & 13443 & 0.3 \\
\hline
\end{tabular}




\section{Economics}

Drip fertigation with $125 \%$ RDF through NF resulted in higher net returns and $\mathrm{B}$ : $\mathrm{C}$ ratio (Table 2) but it was on par with drip fertigation with $100 \%$ RDF through NF. Drip fertigation through water soluble fertilizers resulted in lower net returns and $\mathrm{B}$ : $\mathrm{C}$ ratio because of higher cost of water soluble fertilizers. Fanish et al., 2011 also reported that use of normal fertilizers for drip fertigation was more economical as compared to water soluble fertilizers due to cost factor.

The study inferred that drip fertigation is beneficial in maize and application of $100 \%$ RDF through normal fertilizers gives maximum benefits in terms of yield and economic point of view. Further we can conclude that use of normal fertilizers are more economical for drip fertigation as compared to water soluble fertilizers in maize.

\section{References}

Asadi M.E., Clemente, S.R., Gupta, D.A., Loof, R. and Hansen, K.G., 2002, Impacts of fertigation via sprinkler irrigation on nitrate leaching and corn yield in an acidsulphate soil in Thailand. Agriculture Water Management, 52(3): 197-213.

Black, C.A. 1971. Methods of soil analysis, part II. American Society of Agronomy, Madison.

Douh, B. And Boujelben, A., 2011, Improving water use efficiency for a sustainable productivity of agricultural system using subsurface drip irrigation. Journal of Agricultural Science and Technology, B1: 881-888.

Fanish, A. S., Muthukrishnan, P. and Manoharan, S., 2011, Drip fertigation in maize based cropping systems. Indian Journal of Agricultural Research., 45(3): 233-238.

Gomez, K.A. and Gomez, A.A. (1984). Statistical procedures for agricultural research. John Wiley and sons, New York.

Hassanli, A.M., Ebrahimizadeh, M.A. and Beecham, S., 2009, The effect of irrigation methods with effluent and irrigation scheduling on water use efficiency and corn yields in an arid region. Agricultural Water Manageme nt, 96: 93-99.

Jackson, M.L. 1973. Soil chemical analysis. Prentice Hall, New Delhi, p498p.

Mahajan, V. 2017, Director's review. Annual maize workshop, MPUAT Udaipur, 2-4 April, 2017.

Olsen, S.R., Cole, C.V., Watanabe F.S. and Dean, L.A. 1954. Estimation of available phosphorus in soils by extraction with sodium bicarbonate. USDA Circ 939:19.

Patil, S. A., Mahadkar, U. V. and Gosavi, S. P. 2011. Effect of irrigation and fertigation on yield and its components in sweet corn (Zea mays Saccharata) under medium black soils of North Konkan. Journal of Agriculture Research and Technology, 36 (2): 223-226.

Rangaswamy, R. 2006. Atext book of agricultural statistics, New Age, New Delhi.

Subbaiah, B.V. and Asija, G.L. 1956. A rapid procedure for determination of available nitrogen in soil. Current Science, 25:259262.

Walkley, A. And Black, I.A. 1934. An examination of Degtjareff method for determining soil organic matter and a proposed modification of the chromic acid titration method. Soil Sci 37:29-37.

\section{How to cite this article:}

Richa Khanna, T. Sheshadri and Subhash Chandra. 2018. Effect of Drip Fertigation on Productivity and Economics of Maize (Zea mays L.) in Eastern Dry Zone of Karnataka, India. Int.J.Curr.Microbiol.App.Sci. 7(05): 821-825. doi: https://doi.org/10.20546/ijcmas.2018.705.100 